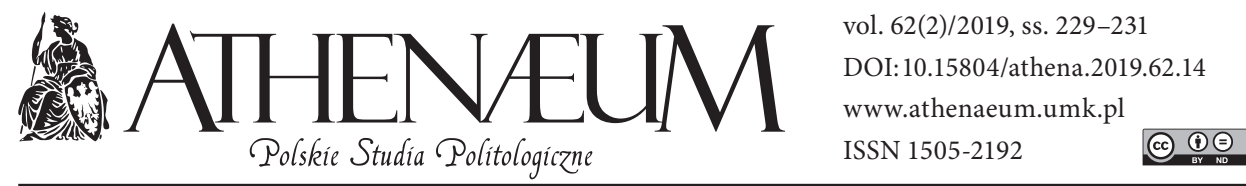

Simona E. Merati, Muslims in Putin's Russia: Discourse on Identity, Politics, and Security, Palgrave Macmillan, Cham 2017, ss. 241

\title{
Kamil Pietrasik*๑
}

Islam w Rosji jest od 1991 roku, czyli po upadku Związku Sowieckiego, religią najszybciej rozwijającą się na tym obszarze, a także najczęściej badaną przez naukowców nie tylko rosyjskich, ale także spoza Rosji. Również m.in. badaczka Simona E. Merati, która specjalizuje się w sprawach dotyczących Rosji, Azji Centralnej oraz Kaukazu, spróbowała skupić się w swoich badaniach na uwarunkowaniach muzułmanów w Rosji. Stała się tym samym autorką bardzo ciekawej w mojej ocenie pracy dotyczących wyznawców islamu w Rosji za prezydentury Borysa Jelcyna czy Władimira Putina.

Autorka słusznie na początku wstępu wzmiankowała, iż według szacunków w Rosji mieszka 16 milionów muzułmanów, zaś islam jest drugą najważniejszą religią w kraju, po chrześcijańskim prawosławiu. S. Merati nie omieszkała wspomnieć

* Uniwersytet Łódzki, Wydział Studiów Międzynarodowych i Politologicznych. o faktycznej liczbie muzułmanów w Rosji, mówiąc, iż brak jest dostępnych statystyk. Szacunki wahają się od 12 do 20 milionów, chociaż według większości komentatorów prawidłowa liczba to około 16 milionów. Jednak pomimo tej znaczącej obecności ogólny obraz Rosji jest słowiański, chrześcijańsko-prawosławny. Z kolei inne grupy w ocenie $S$. Merati, $w$ tym muzułmanie, są często postrzegane jako raczej odrębne mniejszości, zwłaszcza przez obserwatorów spoza Rosji.W dalszej części wstępu autorka scharakteryzowała muzułmanów oraz islam w Rosji, podając ich uwarunkowania, przy jednoczesnym wskazaniu użytych w tej pracy metod badawczych. Autorka, podejmując się niniejszego tematu, wybrała następujące techniki badawcze: analizę źródeł tekstowych lub socjopolitycznych analiz z pozytywnym rezultatem. Głównymi źródłami tej książki była analiza tekstów w językach rosyjskim, a także angielskim. W języku rosyjskim na temat islamu rosyjskiego, autorstwa autorytetów z najdalszych 
zakątków świata, instytucji religijnych, środowisk akademickich, społeczności lokalnych, mediów publicznych i niezarejestrowanych, podziemnych grup. Analizowane źródła zostały wydane zarówno $\mathrm{w}$ formie drukowanej (książki, czasopisma, czasopisma i gazety), jak i w formie elektronicznej (w tym między innymi oficjalne strony internetowe władz religijnych czy publicznych, gazet, kanałów telewizyjnych i blogów). Zakończeniem rozszerzonego wstępu są m.in. stwierdzenia, które mówią, iż odrodzenie panturkizmu (szczególnie w Tatarstanie) było powszechnym i popularnym zjawiskiem w następstwie upadku Związku Sowieckiego w 1991 roku. Różnoraką zachętę, którą rosyjscy muzułmanie często otrzymywali ze strony Turcji i Iranu, często interpretowały zarówno władze państwowe, jak i komentatorzy, jako zbędne, obce ingerencje w wewnętrzne sprawy Rosji. Kolejnym rozdziałem jest The Identity of Muslims of Russia, w którym autorka skupia się między innymi na przedstawieniu geografii wyznawców islamu w Rosji. Warto wskazać, iż rozdział ten został poświęcony głównie okresowi postsowieckiemu, ale także autorka pochyliła się nad omówieniem wyrażenia „rosyjska idea”, który w jej ocenie odnosi się do ogólnej konceptualizacji rosyjskiej tożsamości wypracowanej w XIX i XX wieku. Mówiąc dokładniej, ów pomysł jest tytułem bardzo istotnego eseju rosyjskiego filozofa Nikołaja Aleksandrowicza Bierdiajewa, opublikowanego w 1946 r., w którym zaprezentowano koncepcje mające za pomocą chrześcijaństwa skonsolido- wać rozległe i różnorodne Imperium Rosyjskie.

W kolejnym rozdziale Muslims of Russia Communities autorka skupia się na omówieniu konfrontacji między wyznawcami prawosławia a islamu na terytorium Federacji Rosyjskiej, ale także w wybranych przez nią regionach tego kraju, przybliża np. sytuację muzułmanów w Kaukazie Północnym. Następny rozdział Russia’s Islamic Religious Institutions and the State to pochylenie się głównie nad kwestiami organizacji muzułmańskich oraz ich stosunkiem względem prawosławnych organizacji religijnych. Rozbrzmiewa pytanie, jakie jest znaczenie religii w oczach rządu rosyjskiego.

Islam and Security in Russia to rozdział, w którym spróbowano zobrazować w dość prosty sposób zagrożenie fundamentalistów islamskich i grup radykałów muzułmańskich dla bezpieczeństwa Federacji Rosyjskiej. Kolejny rozdział Islam, Terrorism, and Revolution in Russia jest nieco podobny do poprzedniego, lecz tak naprawdę jest to ukazanie wpływu zjawiska terroryzmu na Federację Rosyjską oraz na wyznawców islamu w tym kraju. Ciekawe jest to, iż autorka dokonała konfrontacji między polityką a islamem oraz terroryzmem. Przedostatni rozdział The Role of Islam in Russia's Geopolitical Vision oznacza wskazanie, iż islam odgrywa w rosyjskiej polityce i strategii geopolitycznej ogromną rolę, gdyż władze rosyjskie, utrzymując pozytywne stosunki ze środowiskami i przedstawicielami muzułmańskimi, mają dobre relacje z krajami 
muzułmańskimi - jak autorka wskazuje m.in. z: Islamską Republiką Iranu, Tadżykistanem. Poruszone zostały również motywy panturkalizmu i panislamizmu, które po ich ponownym rozkwicie w latach 90 . XX wieku straciły na popularności na obszarze rosyjskim, jednak mimo to są zauważalne w życiu społeczności muzułmańskich i tym samym mogą po pewnym czasie oczekiwania pojawić się ze zdwojoną siłą.

Warto nadmienić, iż w rozdziale tym autorka poświęciła swoją analizę podejściu Federacji Rosyjskiej wobec muzułmanów z Półwyspu Krymskiego po jego aneksji. Natomiast w ostatnim rozdziale Conclusions $\mathrm{w}$ omawianej pracy naukowej autorka nakreśla dla przyszłych badaczy, którzy podejmą się badania nad tą problematyką, wskazówki oraz sugeruje, na co należałoby zwrócić uwagę podczas prowadzenia badań, a także w jaki sposób je prowadzić.

$W$ recenzowanej pracy naukowej można napotkać zauważalny błąd. Otóż po przeczytaniu opisu wydarzeń, sytuacji, jak np. debaty w programie prowadzonym przez Władimira Sołowjewa Poedinok, można wywnioskować, iż chodzi w niej o Władimira Żyrinowskiego, lidera Liberalno-Demokratycznej Partii Rosji, a nie - jak podała autorka $\mathrm{w}$ środku pracy oraz $\mathrm{w}$ indeksie osób, wydarzeń i innych istotnych kwestii dotyczących poruszanej problematyki - Giennadija Żyrinowskiego. Jednak ów błąd absolutnie w ocenie autora recenzji nie wpływa znacząco na wartość recenzowanej pracy Simony E. Merati, albowiem badacze Wschodu, systemu politycznego w Rosji czy historii państwa rosyjskiego/sowieckiego wiedzą, iż osoba Giennadija Żyrinowskiego nie istnieje (bynajmniej, jeśli chodzi o świat polityki i aspekty historyczne). Recenzowana książka prezentuje niezwykle ciekawe spostrzeżenia nad wieloma ważnymi zagadnieniami dotyczącymi islamu w Rosji, a także jego wyznawców na obszarze nie tylko rosyjskim, ale również w kontekście historycznym w republikach sowieckich (chociażby środkowoazjatyckie republiki związkowe). Walorem pracy jest trafny - dokonany przez autorkę - wybór źródeł oraz ocena ich znaczenia w stosunku do innych źródeł oraz kontekstów: są to dwa główne wyzwania związane $\mathrm{z}$ analizą, która była istotną przesłanką podjętych w tej pracy rozważań. Recenzowana praca jest cennym źródłem dla ekspertów kwestii wschodnich, religioznawców czy naukowców, zajmujących się kwestiami dotyczących islamu i muzułmanów, albowiem może stanowić skuteczne rozszerzenie wiedzy na temat historycznych oraz aktualnych losów muzułmanów w Rosji. 